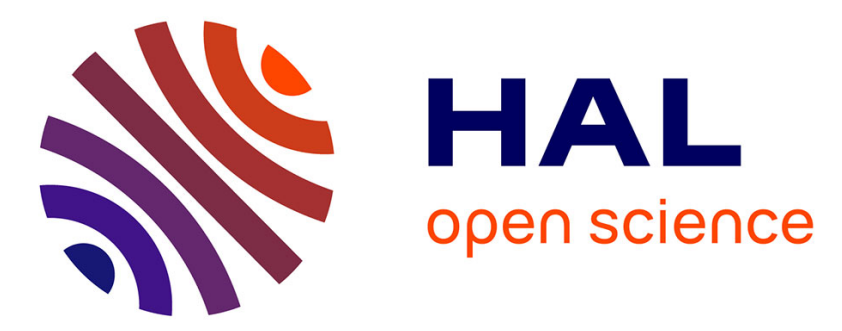

\title{
Electrochemical nickel-catalyzed Migita cross-coupling of 1-thiosugars with aryl, alkenyl and alkynyl bromides
}

\author{
Mingxiang Zhu, Mouad Alami, Samir Messaoudi
}

\section{To cite this version:}

Mingxiang Zhu, Mouad Alami, Samir Messaoudi. Electrochemical nickel-catalyzed Migita crosscoupling of 1-thiosugars with aryl, alkenyl and alkynyl bromides. Chemical Communications, 2020, 56 (32), pp.4464-4467. 10.1039/D0CC01126F . hal-03036460

\section{HAL Id: hal-03036460 https://hal.science/hal-03036460}

Submitted on 2 Dec 2020

HAL is a multi-disciplinary open access archive for the deposit and dissemination of scientific research documents, whether they are published or not. The documents may come from teaching and research institutions in France or abroad, or from public or private research centers.
L'archive ouverte pluridisciplinaire HAL, est destinée au dépôt et à la diffusion de documents scientifiques de niveau recherche, publiés ou non, émanant des établissements d'enseignement et de recherche français ou étrangers, des laboratoires publics ou privés. 
ARTICLE TYPE

\title{
Electrochemical nickel-catalyzed Migita cross-coupling of 1-thiosugars with aryl, alkenyl and alkynyl bromides
}

\author{
Mingxiang Zhu, ${ }^{\mathrm{a}}{\text { Mouad } \text { Alami }^{\mathrm{a}} \text { and Samir Messaoudi }}^{\mathrm{a}}{ }^{*}$ \\ Received (in $X X X, X X X)$ Xth $X X X X X X X X X 20 X X$, Accepted Xth XXXXXXXXX 20XX \\ ${ }_{5}$ DOI: 10.1039/b000000x
}

Here we report a simple route towards the synthesis of thioglycosides, in which electrochemical cross-coupling is used to form the S-C glycosidic bond from protected and unprotected thiosugars with functionalized aryl bromides 10 under base free conditions. The reaction manifold that we report here demonstrates the power of electrochemistry to access highly complex glycosides under mild conditions.

1-Thioglycosides have emerged as a privileged class of glycosides with a diverse range of potential applications. ${ }^{1}$ These

15 glycomimetics are known to be more robust towards enzymatic cleavage under biological conditions. ${ }^{2}$ Representative active glycosides with a thioether linkage are discolosed in Figure 1, including hSGLT1 inhibitor, ligand of lectine A, cytotoxic Hsp90 inhibitor, antimicrobial agent as well as galactin-3-inhibitors. 20 Moreover, thioglycosides are well known to be useful and versatile reactive intermediates in organic synthesis. ${ }^{3}$

At present, for the functionalization of glycosyl thiols, various catalytic systems based on palladium, ${ }^{4}$ nickel ${ }^{5}$ and copper ${ }^{6}$ have been reported (Figure 1,a-b). ${ }^{7}$ Despite their high interest, these 25 methods require the use of basic conditions with high catalyst loadings (30 mol\% in the case of Ni-catalysis) or precious metals such as Pd-catalyst with specially designed ligands. ${ }^{8}$ In addition, an elevated reaction temperature (up to $120{ }^{\circ} \mathrm{C}$ cases of $\mathrm{Pd}-$ or $\mathrm{Cu}$-catalysis), and long reaction times often limit the 30 practicability or the scope of substrates. Moreover, in all these cases the coupling is effective with only aryl iodides, however the cross-coupling with aryl bromides is rather unexplored. To address these issues, we have reported recently a $\mathrm{Ni} / \mathrm{Ru}$ dual photocatalyzed arylation of thiosugars with aryl iodides under 35 base-free conditions (Figure 1,c). ${ }^{9}$ However, the more available and less expensive aryl bromides are still unreactive under these photoredox conditions. Only few examples were reported with yield never exceeded $43 \%$ yield. Moreover, this method was limited to only protected thiosugars. This set of limitations clearly 40 indicates that glycosyl thiols often behave as a rather special and challenging class of thiol nucleophiles for transition-metalcatalyzed thio-functionalization.

\footnotetext{
a BioCIS, Univ. Paris-Sud, CNRS, University Paris-Saclay, Châtenay-Malabry, France Tel: + (33) 0146835887; E-mail: samir.messaoudi@u-psud.fr

$45+$ Electronic Supplementary Information (ESI) available: General, experimental procedures for starting materials and ${ }^{1} \mathrm{H}$ and ${ }^{13} \mathrm{C}$ spectra for all new compounds. See DOI: 10.1039/b000000x/
}

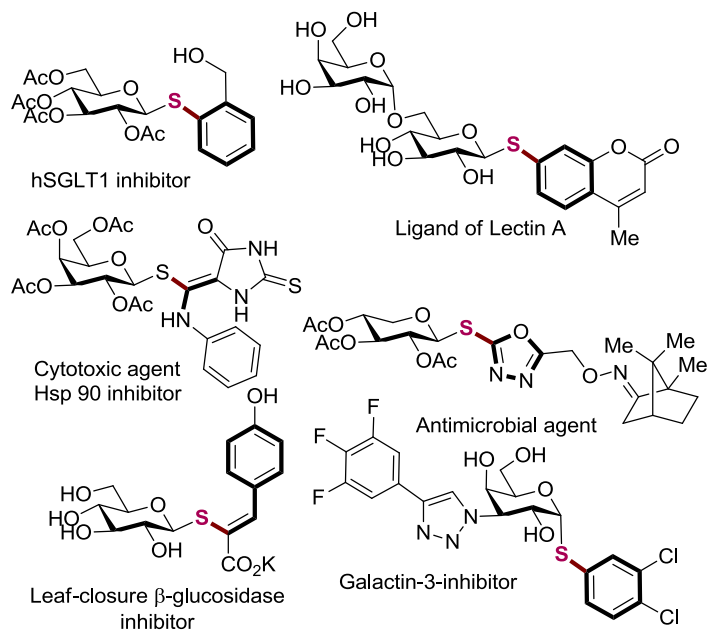

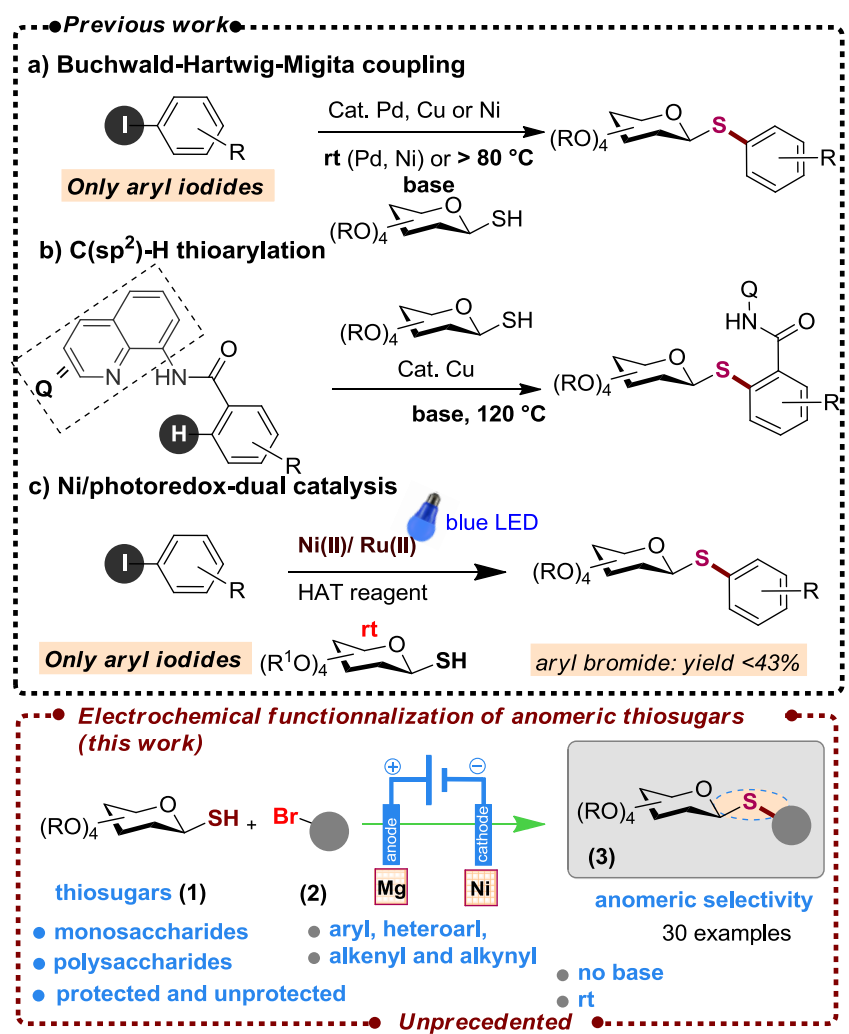

${ }_{50}$ Figure 1. Examples of natural products, bioactive thioglycosides, and catalytic strategies to access to thioglycosides $\mathbf{3}$. 
Because of the high importance of thioglycosides, the development of a general method for the coupling of both aryl bromides and iodides to protected and unprotected thiosugars under room temperature and without an external base remains a 5 challenging task.

In recent years, electrosynthesis ${ }^{10}$ has emerged as a remarkably efficient tool for organic cross-coupling reactions through the use of less precious catalysts, waste-free and inexpensive electric current, thereby avoiding stoichiometric amounts of toxic and 10 costly chemical reagents limiting our impact on the environment. Usually, this method was used successfully in $\mathrm{C}-\mathrm{H}$ activation process fort the formation of $\mathrm{C}-\mathrm{C}$ and $\mathrm{C}$-heteroatom bonds $(\mathrm{C}-\mathrm{O}, \mathrm{C}-\mathrm{P}$, and $\mathrm{C}-\mathrm{N})$ through the directing group strategy. ${ }^{11}$ However, electrochemical $\mathrm{C}$-heteroatom bond formation via 15 cross coupling of nucleophiles with aryl (pseudo)halides was less explored. ${ }^{12}$ In particular, methods which use electrosynthesis to form $\mathrm{C}-\mathrm{S}$ bonds are rare. To the best of our knowledges, only one study from Mei et al. reported the cross-coupling reaction of thiophenols with aryl halides. ${ }^{13}$ The authors showed elegantly 20 that this approach allows thiolation of aryl halides. However, this method exhibited several limitations with regards to potential applications: $i$ ) the use of a large excess of the thiophenol partner (3 equiv) which can be prohibitive for larger scale reactions; $i$ ) the scope with respect to the thiols was limited to 25 unfunctionalized thiophenols, thus precluding many synthetic applications. Moreover, the S-arylation of functionalized and complex alkyl thiols bearing free hydroxyl or amino groups such as thiosugars under electrochemistry has never been studied, probably because of the polyhydroxylated complexity of 30 carbohydrates. Herein, we became interested in whether the S(hetero)arylation of 1-thiosugars could be performed by the electrochemical process. The present study is presented (Figure 1).

To initiate this study, we conducted this electrochemical 35 thioglycosylation by coupling of tetra- $O$-acetylated 1 -thio- $\beta$-Dglucopyranose 1a with 4-bromobenzotrifluoride $\mathbf{2 a}$ as a model study under various reaction conditions. Representative results from this study are summarized in Table 1 . The reaction of 1a (1 equiv) with 2 a (3 equiv) was first investigated by using constant40 current electrolysis at $4.0 \mathrm{~mA}$ in the presence of $\mathrm{NiBr}_{2}$.diglyme (10 mol\%), 4,4'-di-tert-butyl-2,2'-bipyridine (di- $t$ Bubpy) (10 $\mathrm{mol} \%$ ), $\mathrm{LiBr}$ (4 equiv) in DMF at room temperature for $6 \mathrm{~h}$ within an undivided cell (Table 1 , entry 2). Pleasingly, these conditions afforded the $\mathbf{3 a}$ in a moderate $54 \%$ yield as a single $\beta$ 45 anomer $\left(J_{1,2}=9 \mathrm{~Hz}\right)$ (See ESI). Interestingly, decreasing the amount of the bromide partner $2 \mathbf{a}$ from 3 equiv to 1 equiv furnished the thioglucoside $\mathbf{3 a}$ in a good $74 \%$ yield (entry 1). Using other anodes such as Zn was not effective (entry 9). In addition, reaction with DMA instead DMF was less efficient and ${ }_{50}$ gave product 3a in only $47 \%$ yield (entry 11 ). Interestingly, when the current was increased up to $8 \mathrm{~mA}$, the reaction time was shortened to $3 \mathrm{~h}$ and 3a was isolated in $74 \%$ yield (entry 5). Finally, performing the coupling reaction with $20 \mathrm{~mol} \%$ of $\mathrm{NiBr}_{2}$.diglyme and $20 \mathrm{~mol} \%$ of di- $t$ Bubpy furnished 3a in $80 \%$ 55 yield (entry 10). Negative controlling experiments demonstrated the catalyst, the $\mathrm{LiBr}$ and the current are necessary (entries 6-8).
Table 1. Optimization of the coupling reaction of $\mathbf{1 a}^{[\mathrm{a}]}$

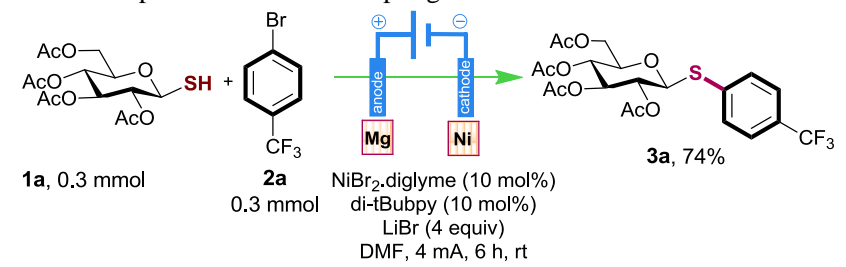

\begin{tabular}{lll}
\hline Entry & Deviation from the standard conditions & Yield $(\%)^{b}$ \\
\hline 1 & none & 74 \\
2 & $0.3 \mathrm{mmol}$ of $\mathbf{1 a}$ and $0.9 \mathrm{mmol}$ of $\mathbf{2 a}$ & 54 \\
3 & $0.6 \mathrm{mmol}$ of $\mathbf{1 a}$ and $0.3 \mathrm{mmol}$ of $\mathbf{2 a}$ & 73 \\
4 & $2 \mathrm{~mA}, 12 \mathrm{~h}$ & 71 \\
5 & $8 \mathrm{~mA}, 3 \mathrm{~h}$ & 74 \\
6 & No LiBr & 0 \\
7 & No catalyst & trace \\
8 & No electric current & 0 \\
9 & Zn instead of Mg & 28 \\
10 & 20 mol\% Ni.cat and 20 mol\% Dttbpy & 80 \\
11 & DMA instead of DMF & 47
\end{tabular}

${ }^{a}$ Reactions conditions: $\mathrm{Mg}$ anode, $\mathrm{Ni}$ foam cathode, $\mathbf{1 a}(0.3 \mathrm{mmol}), \mathbf{2}$ $60(0.3 \mathrm{mmol}), \mathrm{NiBr}_{2}$.diglyme (10 mol\%), di-tBubpy (10 mol\%), LiBr (1.2 $\mathrm{mmol})$, DMF (0.3 M), undivided cell, constant current $=4 \mathrm{~mA}$, (Ar) room temperature, 6 h. ${ }^{b}$ Isolated yield.

With these encouraging results, we investigated next, the scope and limitations for this electrochemical process by systematically 65 varying the nature of the bromide electrophile 2 . As showed in Table 2, all the S-arylations of tetra- $O$-acetylated 1-thio- $\beta$-Dglucopyranose 1a proceeded cleanly and selectively in good yields. Cross-coupling of $\mathbf{1 a}$ with aryl bromides bearing various functions $(-\mathrm{CN},-\mathrm{Cl},-\mathrm{F},-\mathrm{CF} 3,-\mathrm{CHO}$ and $-\mathrm{OMe})$ have been 70 successfully achieved under room temperature to afford the corresponding thioglycosides (3a-m) in yields up to $87 \%$. In addition, the presence of an ortho substitution at the aromatic ring of the coupling partner do not affect the coupling process as compounds $\mathbf{3 h}$ and $\mathbf{3 k}$ were obtained in $80 \%$ and $77 \%$ yields, 75 respectively. It is noteworthy that a selectivity was observed when a tribromobenzene was used, and only a di-glycosylated product 3m was obtained in $70 \%$ yield even after running the coupling with longer reaction time (6h) and using 6 equiv of $\mathbf{1 a}$. One can be noted that, 3-bromonaphtalene is less reactive at 80 current conditions than 2-bromonaphatelene giving the desired Snaphtylglycoside $\mathbf{3 j}$ in only $22 \%$ yield (vs $77 \%$ with 2bromonaphatelene). However this yield could be increased significantly (73\% yield) when 3 -iodonaphtalene. The same low reactivity was observed with $p$-bromoanisole $v s p$-iodoanisole ${ }_{85}$ (compound 31, 15\% vs 83\%). Interestingly, couplings with heteroaryl bromides derived from quinoline and pyridine have also been successful, furnishing $\mathbf{3 n}, \mathbf{o}$ in $46 \%$ and $86 \%$ yields, respectively. Next, we moved on to investigate the reactivity of a series of alkene and alkyne bromides. Pleasantly, both aryl- and 90 alkyl- substituted alkene bromides ((E)-1-(2-bromovinyl)-4methoxybenzene, $E$ - $\beta$-styryliodide, (E)-1-bromooct-1-ene)) and 2-bromo-1H-indene were transformed efficiently into alkenyl thioglycosides 3p-s in excellent yields. Finally, alkynylthioglycosides $\mathbf{3 t}-\mathbf{u}$ were also easily prepared in good yields 95 from corresponding 1-(bromoethynyl)-4-methoxybenzene and 3- 
Table 2 Scope of Coupling of Thioglucose 1a with Halo(hetero)arenes, Alkenyl Halides and Alkynyl Bromides 2

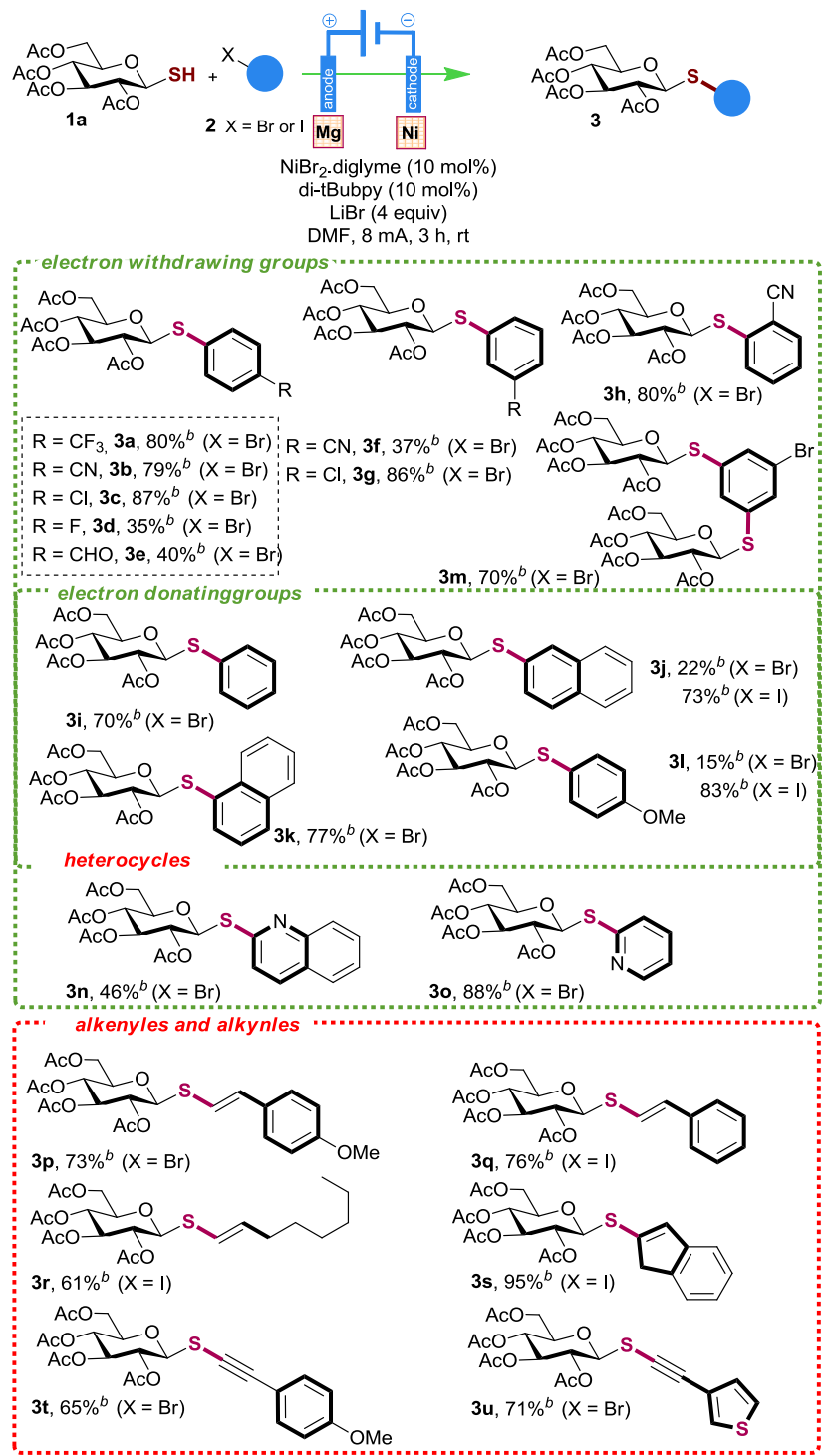

${ }^{a}$ Reactions conditions: $\mathrm{Mg}$ anode, $\mathrm{Ni}$ foam cathode, $1 \mathrm{a}(0.3 \mathrm{mmol}), \mathbf{2}$ 5 (0.3 mmol), $\mathrm{NiBr}_{2}$.diglyme (10 mol\%), di-tBubpy (10 mol\%), LiBr (1.2 mmol), DMF $(0.3 \mathrm{M})$, undivided cell, constant current $=8 \mathrm{~mA}, \mathrm{~N}_{2}$ protection, room temperature, $3 \mathrm{~h} .{ }^{b}$ Isolated yield.

(bromoethynyl)thiophene by this electrochemical method.

10 The successful synthesis of thioglucosides 3a-u from tetra- $O$ acetylated 1-thio- $\beta$-D-glucopyranose $1 \mathrm{a}$ and various aryl bromides under our optimized electrochemical conditions encouraged us to investigate other glycosyl thiols. As depicted in Table 3, this coupling reaction tolerates different sugars such as ${ }_{15} \mathrm{O}$ - benzoylated 1 -thio- $\beta$-D-glucopyranose, thio- $\beta$-Dgalactopyranose and 1-thio- $\beta$-D-fucopyranose which furnished the thioglycosides 4a-c in yields up to $95 \%$. In addition, this coupling could be applied successfully to the more complex and biologically relevant saccharide derivatives thio- $\beta$-D-cellobiose 20 and thio- $\beta$-D- maltotriose delivering $\mathbf{4 d}$ and $\mathbf{4 e}$ in $90 \%$ and $88 \%$ yields, respectively.
Table 3. Scope of 1 thio- $\beta$-glycosyls $\mathbf{1 b - g}{ }^{a}$

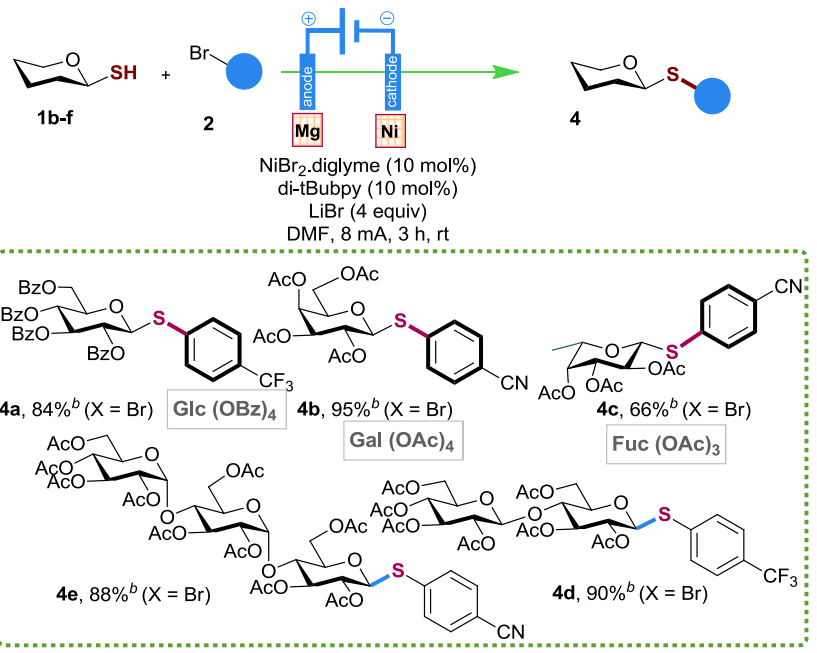

${ }^{a}$ Reactions conditions: $\mathrm{Mg}$ anode, $\mathrm{Ni}$ foam cathode, $\mathbf{1 b - f}(0.3 \mathrm{mmol}), \mathbf{2}$ 25 (0.3 mmol), $\mathrm{NiBr}_{2}$.diglyme (10 mol\%), di-tBubpy (10 mol\%), LiBr (1.2 mmol), DMF $(0.3 \mathrm{M})$, undivided cell, constant current $=8 \mathrm{~mA}, \mathrm{~N}_{2}$ protection, room temperature, $3 \mathrm{~h} .{ }^{b}$ Isolated yield.

One of the most important task in this area of organometallic chemistry is to discover mild and general methods for easy 30 functionalization of polyhydroxylated compounds with high selectivity without using any protection/deprotection sequence. To further show the synthetic use of our protocol, we evaluated whether the S-arylation of unprotected thiosugars could be realized by this electrochemical method. To our delight, the 35 reaction of unprotected thio- $\beta$-D-glucose and thio- $\beta$-D-cellobiose yielded the respective products $\mathbf{5 a}$ and $\mathbf{5 b}$ in good yields, and no side products arising from the $O$-arylation were observed (Scheme 1).

Scheme 1. Unprotected thiosugars and cysteine-aminoacid as thiols

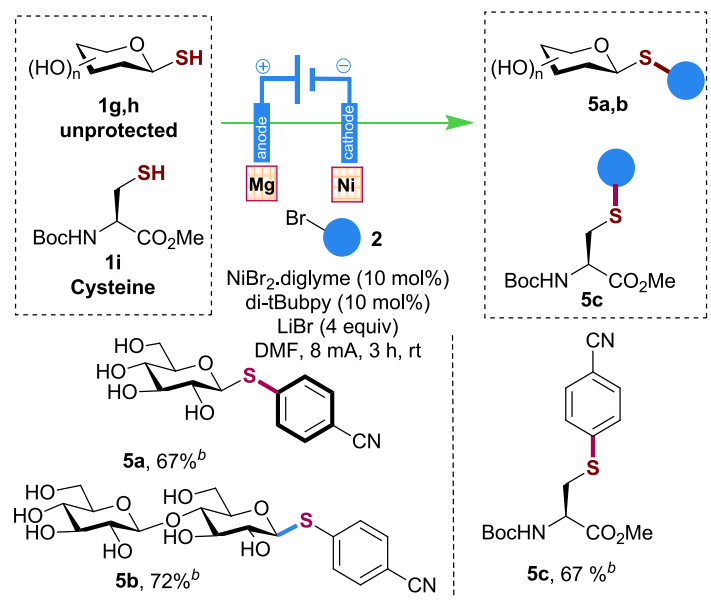

${ }^{40}$ Reactions conditions: $\mathrm{Mg}$ anode, $\mathrm{Ni}$ foam cathode, $\mathbf{1 g - i}(0.3 \mathrm{mmol}), \mathbf{2 a}$ (0.3 mmol), $\mathrm{NiBr}_{2}$.diglyme (10 mol\%), di-tBubpy (10 mol\%), LiBr (1.2 mmol), DMF $(0.3 \mathrm{M})$, undivided cell, constant current $=8 \mathrm{~mA}, \mathrm{~N}_{2}$ protection, room temperature, $3 \mathrm{~h} .{ }^{b}$ Isolated yield

${ }_{45}$ Finally, as part of our interest in developing new methods to peptide and protein bioconjugation, we considered it worthwhile to investigate the reaction of cysteine aminoacid with aryl bromides (Scheme 1). Direct arylation of cysteine-containing peptides has only been reported using the precious Pd-catalysis. ${ }^{14}$ 
To this end, we tested the reaction of L-cysteine with $p$ cyanophenyl bromide and we were pleased to observe the formation of the $\mathrm{S}$-arylated cysteine $\mathbf{5 c}$ in $67 \%$ yield (Scheme 1). This result represent the first example of diversification of 5 cysteine under electrochemical approach and may open new way to the bioconjugation of peptides and protein through this methodology.

In summary, we described here the first electrochemical method of coupling of various anomeric glycosyl thiols with aryl 10 bromides. This method demonstrates unprecedented reactivity in regard to bromide partners (heteroaryl, alkenynyl and alkenyl bromides) and selectivity, including reactions with unprotected thiosugars, and cysteine aminoacid. Further studies on the applications of this method on the S-arylation of more complex 15 polysaccharides and cysteine containing peptides are ongoing.

\section{Acknowledgements}

Authors acknowledge support of this project by CNRS, University Paris-Saclay, ANR (CarNuCat, ANR-15-CE29- 0002), and by la Ligue Contre le Cancer through an Equipe Labellisée 202014 grant. We also thank the China Scholarship Council for a fellowship (CSC) to Mingxiang Zhu.

\section{Notes and references}

1.(a) For general reviews, see: a) H. Driguez, Glycoscience Synthesis $O f$ Substrate Analogs And Mimetics. 1997, 187, 85-116; b) Z. J. Witczak,

25 Curr. Med. Chem. 1999, 6, 165-178; c) K. Pachamuthu, R. R. Schmidt, Chem. Rev. 2006, 106, 160-187; d) M. Samuni-Blank, I. Izhaki, M. D. Dearing, Y. Gerchman, B. Trabelcy, A. L. W. H. Karasov, Z. Arad, Curr. Biol. 2012, 22, 1218-1220; e) G. Lian, X. Zhang, B. Yu, Carbohydr. Res. 2015, 403, 13-22. For Selected articles: f) F.

30 Castaneda, A. Burse, W. Boland, R. K. H. Kinne, Int. J. Med. Sci. 2007, 4, 131-139; g) J. Rodrigue, G. Ganne, B. Blanchard, C. Saucier, D. Giguere, T. C. Shiao, A. Varrot, A. Imberty, R. Roy, Org. Biomol. Chem. 2013, 11, 6906-6918; h) G. H. Elgemeie, A. B. Farag, K. M. Amin, O. M. El-Badry, G. S. Hassan, Eur. J. Med. Chem. 2014, 4, 814-

35 833; i) M. R. Aouad, Nucleos. Nucleot. Nucl. 2016, 35, 1-15; j) E. Kato, H. Nagano, S. Yamamura, M. Ueda, Tetrahedron, 2003, 59, 5909-5917; k) M. Schnabelrauch, A. Vasella, S. G. Withers, Helv. Chim. Acta. 1994, 77, 778-799; 1) M. Adinolfi, M. d'Ischia, A. Iadonisi, L. Leone, A. Pezzella, S. Valerio, Eur. J. Org. Chem. 2012,

40 23, 4333-4338; m) K. Shirota, Y. Kato, K. Suzuki, Y. Sugiyama, J. Pharmacol. Exp. Ther. 2001, 299, 459-467; n) R. Caraballo, M. Sakulsombat, O. Ramstrçm, ChemBioChem 2010, 11, 1600-1606.

2. a) C. S. Rye, S. G. Withers, Carbohydr. Res. 2004, 339, 699-703; b) B. B. Metaferia, B. J. Fetterolf, S. Shazad-ul-Hussan, M. Moravec, J. A. 5 Smith, S. Ray, M. -T. Gutierrez-Lugo, C. A. Bewley, J. Med. Chem. 2007, 50, 6326-6336; c) F. Castaneda, A. Burse, W. Boland, R. K.-H. Kinne, Int. J. Med. Sci. 2007, 4, 131-139.Full Paper

3.a) J. D. C. Codee, R. E. J. N. Litjens, L. J. van den Bos, H. S. Overkleeft, G. A. van der Marel, Chem. Soc. Rev. 2005, 34, 769-782;

50 for selected examples, see: b) M. Johannes, M. Reindl, B. Gerlitzki, E. Schmitt, A. Hoffmann-Rçder, Beilstein J. Org. Chem. 2015, 11, 155161; c) D. Budhadev, B. Mukhopadhyay, Carbohydr. Res. 2014, 384, 51-55; d) N. Basu, S. Kumar Maity, R. Ghosh, RSC Adv. 2012, 2, 12661-12664; e) P. Verma, R. Raj, B. Roy, Tetrahedron: Asymmetry

55 2010, 21, 2413-2418; f) C. D. Xiong, L. H. Zhang, X. S. Ye, Adv. Synth. Catal. 2008, 350, 1696-1700; g) B. Roy, K. Pramanik, B. Mukhopadhyay, Glycoconjugate J. 2008, 25, 157-166; h) Y. Zeng, Z. Wang, D. Whitfield, X. Huang, J. Org. Chem. 2008, 73, 7952-7962; i) M. Fridman, V. Belakhov, L. V. Lee, F. -S. Liang, C. -H. Wong, T. 60 Baasov, Angew. Chem. Int. Ed. 2005, 44, 447-452; Angew. Chem. 2005, 117, 451-456.

4. a) E. Brachet, J. -D. Brion, S. Messaoudi, M. Alami, Adv. Synth. Catal. 2013, 355, 2627-2636; (b) E. Brachet, J. -B. Brion, S. Messaoudi, M.
Alami, Adv. Synth. Catal. 2013, 355, 477-490; c) A. Bruneau, M. 65 Roche, A. Hamze, J. -D. Brion, M. Alami, S. Messaoudi, Chem. Eur. J. 2015, 21, 8375-8379; d) R. A. A. AL-Shuaeeb, D. Montoir, M. Alami, S. Messaoudi, J. Org. Chem. 2017, 82, 6720-6728; e) N. Probst, R. Lartia, O. Théry, M. Alami, E. Defrancq, S. Messaoudi, Chem. Eur. J. 2018, 24, 1795-1800; f) D. Montoir, M. Amoura, Z. E. -A. Ababsa, T.

70 M. Vishwanath, E. Yen-Pon, V. Robert, M. Beltramo, V. Piller, M. Alami, A. Aucagne, S. Messaoudi, Chem. Sci., 2018, 9, 8753-8759.

5.E. Brachet, J.-D. Brion, M. Alami, S. Messaoudi, Chem. Eur. J. 2013 19, 15276-15280.

6. (a) P. Nauš, L. Lešetický, S. Smrček, I. Tišlerová, M. Štícha, Synlett 75 2003, 14, 2117-2122; b) A. Chabrier, A. Bruneau, S. Benmahdjoub, B Benmerad, S. Belaid, J.-D. Brion, M. Alami, S. Messaoudi, Chem. Eur. J. 2016, 22, 15006-15010; c) X. Yuan, Y. Kou, L. Yu, Z.-X. Zhang, W. Xue, Org. Chem. Front. 2015, 2, 1604-1607.

7. Fore a recent review, see: N. Ibrahim, M. Alami, S. Messaoudi, Asian. 80 J. Org. Chem. 2018, 7, 2026-2038.

8. For selected Pd-catalyzed thiolation, see: a) M. Sayah, M. G. Organ, Chem. Eur. J. 2013, 19, 16196-16199; b) E. Alvaro, J. F. Hartwig, J. Am. Chem. Soc. 2009, 131, 7858-7868; c) M. Murata, S. L. Buchwald, Tetrahedron 2004, 60, 7397-7403; e) T. Migita, T. Shimizu, Y. Asami,

85 J.-I. Shiobara, Y. Kato, M. Kosugi, Bull. Chem. Soc. Jpn. 1980, 53, 1385-1389; g) M. Kosugi, T. Shimizu, T. Migita, Chem. Lett. 1978, 13 14.

9. M. Zhu, G. Dagousset, M. Alami, E. Magnier, S. Messaoudi, Org. Lett. 2019, 21, 5132-5137.

90 10. For selected reviews on electrochemistry: a) L. Ackermann, Acc. Chem. Res. 2020, 53, 84-104; b) M. Cong , F. Ping, M. Tian-Sheng, ACS Catal. 2018, 8, 7179-7189; c) N. Sauermann, T. H. Meyer, Y. Qiu, L. Ackermann, ACS Catal. 2018, 8, 7086-7103; d) G. S. Sauer, S. Lin, ACS Catal. 2018, 8, 5175-5187; e) S. Tang, Y. Liu, A. Lei, Chem 95 2018, 4, 27-45; f) Y. Jiang, K. Xu, C. Zeng, Chem. Rev. 2018, 118 , 4485-4540; g) S. R. Waldvogel, S. Lips, M. Selt, B. Riehl, C. J. Kampf, Chem. Rev. 2018, 118, 6706-6765; h) K. D. Moeller, Chem. Rev. 2018, 118, 4817-4833; i) C. Ma, P. Fang, T.-S. Mei, ACS Catal. 2018, 8, 7179-7189; j) M. Yan, Y. Kawamata, P. S. Baran, Chem. Rev. $100 \quad 2017,117,13230-13319$.

11. For selected C-heteroatom bond through electrochemistry: a) S. -K Zhang, J. Struwe, L. Hu, L. Ackermann, Angew. Chem. Int. Ed. 2020, 132, 1-7; b) Q. -L. Yang, X. -Y. Wang, J. -Y. Lu, L. -P. Zhang, P. Fang, T. -S. Mei, J. Am. Chem. Soc. 2018, 140, 11487-11494; c) C. 105 Ma, C. -Q. Zhao, Y. -Q. Li, L. -P. Zhang, X. -T. Xu, K. Zhang, T. -S Mei, Chem. Commun. 2017, 53, 12189-12192; d) Y. -Q. Li, Q. -L. Yang, P. Fang, T. -S. Mei, D. Zhang, Org. Lett. 2017, 19, 2905-2908; e) Q. -L. Yang, Y. -Q. Li, C. Ma, P. Fang, X. -J. Zhang, T. -S. Mei, J. Am. Chem. Soc. 2017, 139, 3293-3298; f) K. -J. Jiao, Z. -M. Li, X. -T.

110 Xu, L. -P. Zhang, Y. -Q. Li, K. Zhang, T. -S. Mei, Org. Chem. Front. 2018, 5, 2244-2248; g) Y. Bai, N. Liu, S. Wang, S. Wang, S. Ning, L. Shi, L. Cui, Z. Zhang, J. Xiang, Org. Lett. 2019, 21, 6835-6838.

12. a) J. Xiang, M. Shang, Y. Kawamata, H. Lundberg, S. Reisberg, M. Chen, P. Mykhailiuk, G. Beutner, M. Collins, A. Davies, M. Del Bel, 115 G. Gallego, J. Spangler, J. T. Starr, S. Yang, D. Blackmond, P. S. Baran, Nature 2019, 573, 398-402; b) Y. Kawamata, J. C. Vantourout, D. P. Hickey, P. Bai, L. Chen, Q. Hou, W. Qiao, K. Barman, M. A. Edwards, A. F. Garrido-Castro, J. N. deGruyter, H. Nakamura, K. Knouse, C. Qin, K. J. Clay, D. Bao, C. Li, J. T. Starr, C. Garcia120 Irizarry, N. Sach, H. S. White, M. Neurock, S. D. Minteer, P. S. Baran, J. Am. Chem. Soc. 2019, 141, 6392-6402; c) C. Li, Y. Kawamata, H. Nakamura, J. C. Vantourout, Z. Liu, Q. Hou, D. Bao, J. T. Starr, J. Chen, M. Yan, P. S. Baran, Angew. Chem. Int. Ed. 2017, 56, 1308813093.

125 13. D. Liu, H. Ma, P. Fang, T. Mei, Angew. Chem. Int. Ed. 2019, 58, 5033-5037.

14. (a) E. V. Vinogradova, C. Zhang, A. M. Spokoyny, B. L. Pentelute, S. L. Buch-wald, Nature 2015, 526, 687-691; (b) R. A. Al-Shuaeeb, S. Kolodych, O. Koniev, S. Delacroix, S. Erb, S. Nicolaÿ, J. C. Cintrat, J. 130 D. Brion, S. Cianférani, M. Alami, A. Wagner, S. Messaoudi, Chem. Eur. J, 2016, 22, 11365-11370; (c) J. Willwacher, R. Raj, S. Mohammed, B. G. Davis, J. Am. Chem. Soc. 2016, 138, 8678-8681. 